\title{
SPECIFIC ALLOCATION FUND FOR ENERGY EFFICIENCY TO INCREASE QUALITY OF THE ENVIRONMENT IN INDONESIA (Mekanisme Dana Alokasi Khusus Efisiensi Energi dalam Mendukung Perbaikan Lingkungan di Indonesia)
}

\author{
Joko Tri Haryanto* \\ Centre for Climate Change Financing and Multilateral Policy, \\ Fiscal Policy Office-Ministry of Finance of Indonesia, Jl. Dr Wahidin Raya No 1, Jakarta Pusat. \\ *Korespondensi. No Tel: 628176069905. Fax : 622134831677. Email: djohar78@gmail.com.
}

Diterima: 6 Mei 2014

Disetujui: 16 Februari 2015

\begin{abstract}
Related to the climate change and economic development of environmentally friendly (green economy) issues, the President has committed to reducing emissions of greenhouse gases (GHG) by $26 \%$ on their own sources (BAU), and up to $41 \%$ with international support in 2020 through Presidential Decree No. 61 in 2011 about the National Action Plan for Greenhouse Gas Emission Reduction (RAN-GRK). In addition to regulating the sectors that are considered to be the largest contributor to GHG emissions, the regulation also establishes funding sources RAN-GRK either through the APBN, APBD, as well as a variety of other sources constituted under the legislation. The main research question are; Is specific allocation fund (DAK) can be used to fund energy efficiency?; if so, what procedure should be done? and how monitoring and evaluating of the energy efficiency of the use of DAK ? To answer those questions, researcher using qualitative library research, cross sectional collection of data for intensive analysis, interviews to some leading experts in the field and a number of Focused Group Discussions were also conducted to construct the policy analysis. Based on the analysis of the mechanism of transfer to the regions in Indonesia, it is possible to enlarge of DAK field for energy efficiency by asking Line Minister to proposed mechanism and send to the Ministry of Finance. This can be addressed to support the achievement of environmental friendly activities and reduce the burden of state budget subsidies. Some of things that must be done is to propose the allocation of DAK EE into government programs and to develop a variety of specificized and technical indicators related.
\end{abstract}

Keywords: energy conservation, energy efficiency, energy subsidy, green house gas emission, specific allocation fund.

\begin{abstract}
Abstrak
Terkait dengan komitmen dalam mengatasi dampak perubahan iklim serta isu pengembangan ekonomi rendah karbon, Pemerintah telah mengesahkan Peraturan Presiden (Perpres) Nomor 61 Tahun 2011 tentang rencana Aksi Nasional Penurunan Emisi Gas Rumah Kaca Nasional (RAN-GRK) tahun 2020 sebesar 26\% dengan usaha sendiri dan 41\% dengan bantuan pendanaan asing. Dalam Perpres tersebut telah diatur sektor-sektor apa saja yang dianggap menjadi sumber emiten terbesar termasuk sektor energi, sekaligus adanya kewajiban pendanaan APBN/APBD dalam mengatasinya. Di sisi lain, kegiatan efisiensi energi tercatat sebagai salah satu aksi penurunan emisi GRK yang cukup signifikan dalam sektor energi baik untuk bangunan maupun mesin. Sayangnya kegiatan tersebut membutuhkan investasi yang cukup besar. Akibatnya kegiatan efisiensi energy menjadi tidak menarik. Di sinilah peran pendanaan APBN/ APBD menjadi sangat krusial. Terkait dengan pengaturan pengalokasian pendanaan APBN/APBD inilah peran Kemenkeu menjadi sangat vital, khususnya dalam mekanisme pengalokasian Dana Alokasi Khusus (DAK) yang menjadi kewenangannya. Dari hasil analisis, mekanisme alokasi DAK ternyata memungkinkan untuk ditujukan bagi pendanaan kegiatan efisiensi energi. Namun demikian, mekanisme yang harus dijalankan lebih difokuskan kepada inisiatif Kementerian/Lembaga (K/L) yang berwenang dalam pengusulan alokasi DAK tersebut.
\end{abstract}

Kata kunci: dana alokasi khusus, energi efisiensi, emisi gas rumah kaca, konservasi energi, subsidi energi.

\section{INTRODUCTION}

Energy continues to be one of the crucial issues faced by each country. Appropriate policies in the energy sector will have a positive impact to economic stability. Conversely, improper policy will cause trapping of a country in a state of high economic costs as a result of inefficiencies in the economy of the country round. The population of Indonesia is increasing from year to year due to increased economic growth and a variety of economic activities undertaken by the community will always be followed by the need for significant energy resource. According to the World Bank, Indonesia's economic growth increased from 5.7\% in 2005 to $5.9 \%$ in 2010 , and is projected to reach 
6.6\% by the end of 2012 (Anonymous, 2012 in Setyawan, 2013) and Indonesia's interest to manage and use energy effectively and efficiently as possible.

The burden of energy subsidies from year to year, is a logical consequence of rising incomes and purchasing power and increased economic activity. The high energy subsidy has hindered efforts to encourage the development of different types of alternative energy and renewable energy, because a very large energy subsidies have distorted the market and provide a major obstacle for clean energy investment.

Subsidies for energy become very onerous burden Budget of the state (the state budget). As the fiscal authorities, the Ministry of Finance should strive to nourish from the state budget expenditure on subsidy burden by encouraging energy efficiency initiatives. In this context, the Ministry of Finance has provided various forms of incentives to influence economic actors in order to implement energy savings programs on an ongoing basis eg tax facilities and facilities duty for components / parts and raw materials used to produce energyefficient appliances.

But until now, these incentives have not been able to fully affect the efficient use of energy investment. The perpetrators are still in need of support investment in other forms of support such as low-interest financing. Support is in line with the mandate of Law No. 30 of 2007 on Energy, which is then further regulated by Government Regulation No. 70 of 2009 on Energy Conservation which Article 20 stated that one of the forms of government incentives that can be given is the facility of low interest rates to fund investment energy conservation (Setyawan, 2013).

If we learnt from Thailand's Energy Efficiency Revolving Fund Model (TEERF), this funding get revenue from the excess of levies on fuel at 0.04 THB (USD 0.001) per litre. From the total revenue over the levies, this funding revolve to be the source of funds for supporting the energy efficiency programs and renewable energy and became the forerunner of the establishment of a revolving fund energy efficiency programs. In this program, the maximum loan amount is restricted up to THB 50 million (USD 1.25 million) per project (Grüning et al, 2012).

In order to distribute the funds, the Government of Thailand is involving 11 commercial banks. This funding scheme is provided by the government (DEDE) to the commercial banks through 5 phases. For the phase 1 (period 2003-2006), as a part of the government energy efficiency programs, the government gave a free interest rate financing. Then, the next phases (period 2006-2013), the government charging interest rate to banks with $0.5 \%$.

The bank then lends it to the projects with interest not more than $4 \%$ per year in order to fund energy efficiency projects and renewable energy projects (at that time the Thailand market interest rates is ranging from 6-7\%). These financing schemes can generate additional revenues in average up to USD 50 million per year. As of June 2011, the Energy Conservation Fund has raised more than USD 500 million (Sutabur, 2012).

Related to climate change and economic development of environmentally friendly (green economy) issues, the President has committed to reducing emissions of greenhouse gases (GHG) by $26 \%$ on their own sources (BAU), and up to $41 \%$ with international support in 2020, through Presidential Decree Number 61 in 2011, about the National Action Plan for Greenhouse Gas Emission Reduction (RAN-GRK). Based on this regulation, government has consider $6^{\text {th }}$ sectors as the sources of pollution are industry, energy, forestry and peat land, waste also transportation. In addition to regulating the sectors that are considered to be the largest contributor to GHG emissions, the regulation also establishes funding sources RANGRK either through the APBN, APBD, as well as a variety of other sources constituted under the legislation.

As the fiscal authorities, the Ministry of Finance have to make efforts in order to nourish the APBN. One of the initiatives that need to be supported is an effort to reduce their energy use. In this context, the Ministry of Finance has provided various forms of incentives to affect various economic actors in order to implement energy savings programs are self-sustaining facilities such as tax incentives and import duties for components and raw materials used to produce energy-efficient appliances.

However, these incentives have not been fully influence behavior change in the community and business energy use. Responding to this issue, the expansion is still needed fiscal support in the form of another. One form of fiscal support that is expected by the market participants in order to encourage investment in capital equipment, which is also a best practice in many countries, is funding the scheme through the Specific Allocation Fund (DAK) Energy Efficiency in the mechanism of Transfer to Regions.

In general, DAK has advantages compared to other Regional Transfer component either DAU or $\mathrm{DBH}$, especificly if associated with budget allocation specification purposes. Some DAK 
scheme was already allocated to the sector GHG emission reductions already have DAK funding, such as forestry, agriculture, and environmental sectors. In terms of funding through DAK characteristics, which are focused on the physical activity, as well as the general focus of activity is the activity performed and the affairs of the district and city governments, the context of the funding through the complementary function of DAK funding through Grants.

Within this framework, mechanisms DAKEnergy Efficiency (DAK-EE) is expected not only to encourage investment in projects that are energy efficient, but also can have a positive impact on the reduction of energy subsidies through the efficient use of energy and reduction of greenhouse gas emissions in Indonesia. DAK-EE is expected to occur in energy efficiency projects aimed to reduce electricity subsidies, encourage the use of energyefficient technologies, stimulate the involvement of the financial sector (banking / financial institutions) to support the development of energy conservation and assist efforts to achieve national GHG emission reduction target by 2020 .

Energy conservation activities are expected to contribute to the reduction of GHG emissions by 22:29 million $\mathrm{tCO}_{2}$ by 2020. DAK-EE policy proposal is in line with the program that is being developed by the Ministry of Energy and Mineral Resources. In this regard, the Ministry of Energy in order to improve the implementation of energy conservation in the industrial and building sectors have implemented Partnership Program that provides services and capacity building energy audits free of charge to companies committed to implementing energy audit recommendations.

From a more national perspective, improving energy efficiency may also improve the security of energy supply, lead to employment or productivity gains (including competitive advantages for industry) and alleviate energy poverty. At the more regional level, higher energy efficiency leads to health benefits from lower emissions of local pollutants (e.g. nitrogen oxides and sulfur). Finally, at the company level, improving energy efficiency reduces energy costs and may improve profitability and competitiveness. However, maximizing energy efficiency does not always correspond to maximizing economic efficiency, since the latter implies the optimal use of all resources - not just energy inputs (Sutherland, 1994).

With this explanation, the main research questions on this paper are; Is the specific allocation fund (DAK) can be used to fund energy efficiency?. If yes it does, what procedure should be done and also how to monitoring and evaluating this mechanism. This paper will focuses on the mechanism of DAK for financing energy efficiency and how to build monitoring and evaluation to ensure DAK more efficient and efective.

In general, the concept of energy efficiency is defined as the ratio of energy needs devided by input energy. One of the concept that support energy efficiency is called Trias Energetica Concept. This simple and logical concept can be applied as an effort to achieve energy savings as well as to reduce the reliance on fossil fuel in the context of saving the environment.

There are three fundamental elements of trias energetica concepts i.e. reduce energy demand as much as possible by implementing energy saving measures, utilize renewable energy sources, and use fossil energy as efficiently as possible and only if sustainable sources are inadequate. There were many studies had been discussed about the concepts of energy efficiency. According to Lovin (1976) the concept of energy efficiency can be defined as the economical usage of energy in order to increase the economic output. In the study, Lovin explaining a large number of energy alternatives, renewable, and more environmentally energy compare to fossil fuel.

Soon after its publication, various ideas about energy efficiency began having a significant effect on public policy concept (Golove and Eto, 1996). According to Hinge et al (2004), energy efficiency is defined as how much energy services should be prepared per unit of energy input. Related to economic problems, the economics of energy efficiency is about the question of balancing the costs and benefits. In addition to that, Golove and Eto (1996) mentioned that energy efficiency defined as providing equivalent energy service at lower total cost. There are some debates on energy efficiency due to consumer decisions over energy use.

According to Sanstad and Howarth (1994) the behaviour of energy consumers in deciding energy use is depending on maximization preference. Hinge et al (2004) observed that personal energy user have some considerations i.e. a greater initial cost in buying energy-efficient products over expectation of future cost saving benefit. Other findings from Robinson (1991) the costs and benefits of energy efficiency labelling does not ameliorate decision making of energy user.

Moreover, Stern (1986) observed that individuals tend to overvalue the amounts of energy used and technology saved. Another study, Kirsch (1993) discovered that people who do not understand numerical calculations seems difficult to arrive at a right energy-related decisions. Another 
debates on energy efficiency is regarding the market barriers. Blumstein et al. (1980) observed that energy conservation actions probably hampered by social and institutional barriers, even though there are economically logical responses to the energy crises.

According to Golove and Eto (1996) there are at least seven market barriers were identified: misplaced incentives, lack of access to financing, flaws in market structure, mis-pricing imposed by regulation, decision influenced by custom, lack of information or misinformation, and gold plating and Inseparability of Features. Therefore, decision makers need a mix of sound analysis and pragmatism to establish a good energy efficiency policy.

Empirically, the thrust of engineeringeconomic type analyses suggests that there is a large potential for energy efficiency measures that appear profitable under actual economic and institutional conditions, that is, even if energy prices factors are not at their socially optimal levels (e.g. IPCC 2007). Because of barriers to energy efficiency these seemingly profitable measures are not being adopted.

Barriers at the macro level involve price distortions or institutional failures. In comparison, the literature on barriers at the micro level tries to explain why organizations fail to invest in energy efficiency even though it appears to be profitable under current economic conditions determined at the macro level - a phenomenon that is also known as the "energy efficiency gap" or the "energy efficiency paradox" (Jaffe and Stavins, 1994).

Except the energy efficiency concepts from various researches and studies, the Government of Indonesia has its own definition in regards of energy efficiency concept. According to Government Regulation No. 70 Year 2009 regarding Energy Conservation, the definition of Energy Conservation is systematic efforts, wellplanned and integrated in order to conserve domestic energy resources as well as to enhance the efficiency utilization. Efficiency constitutes one of the implementation step in achieving energy conservation. Energy efficiency generally defined as energy savings.

There are four types of intergovernmental transfer introduced in the law 32/2004 and 33/2004: natural resources revenue sharing, tax sharing, general allocation fund, and specific allocation fund. Among these four types, the general allocation fund may be the most significant for almost all local governments in Indonesia, while the natural resources revenue sharing only matters for few provinces or districts.
Specific allocation fund could be classified as a conditional grant in which local governments will receive the grant if the central government asks them to do certain tasks. Those certain tasks are mostly the central government's interests or in other words, the central government can use the specific allocation fund to direct the regional development in order to fulfill their macro target.

According to the government regulation, this fund can be utilized to improve inter-districts roads, to help the local governments to reach minimum standard of basic services (basic education, water distribution, and health services), to support irrigation system and transmigration program, to overcome environmental problems, and to give specific assistance to very poor areas.

In the government regulation, it is stated that the amount of specific allocation fund depends on the existing fiscal condition. The slow recovery of national economic condition forced the central government to make a conservative budget that focuses more on necessary items such as general allocation fund and neglects, at least temporarily, the specific allocation fund. For the every fiscal year, the specific allocation fund can only be utilized to protect the environment through the reforestation fund that used to be a non-budgetary fund but now becomes a part of the specific allocation fund (Suminto, 2003).

\section{EXPERIMENTAL METHOD}

This paper have an aims to finding mechanism to accelerating energy efficiency through DAK. The type of data that used in this study, mostly on the secondary data obtained from several institutions such as the Ministry of Finance, Directorate General Fiscal Balance and other stakeholders. This research using descriptive analysis by using some technical interpretation of the criteria required in the preparation of DAK process. Library research, cross sectional collection of data for intensive analysis, interviews to some leading experts in the field and a number of Focused Group Discussions were also conducted to construct the policy analysis. Collections of information are compared and developed in order to create a new mechanism to build mechanism of Specific Allocation Fund for Energy Efficiency (DAK-EE).

\section{RESULTS AND DISCUSSION}

DAK allocated to help fund the program in the region / activities under the authority of local and national priorities. DAK is a regional destination 
that can provide infrastructure facilities and infrastructure are adequate public services in accordance with Minimum Service Standards each field. DAK allocated based on three criteria, namely: Common Criteria, Specific Criteria and Technical Criteria. General criteria calculated to see the ability to finance budget needs in the context of regional development reflected from the general revenue budget reduced personnel expenses. In formula form, the General criteria can be shown in equations (1) and (2).

Fiscal Capacity $=$ General Revenue $(A P B D)-$

Apparatus Expenses

General Revenue $(A P B D)=$ Local Own Revenue +

General Allocation Fund + Revenue Sharin

Act 33 of 2004 on Fiscal Balance Between Central Government and Local Government Article 40 Paragraph 3 explains that "specific criteria established by observing the rules legislation and regional characteristics", and added through Government Regulation No. 55 Year 2005 on Fund Balance Article 56 Paragraph 2. "Specific criteria formulated through regional index by the Minister of Finance to consider input from the Minister of Bappenas and Line Ministry.

Specific criteria are used in the calculation DAK allocation of attention: Regulation Legislation a specific area; entire district / city in the province of Papua, West Papua province, and Regional backward / remote, and characteristics areas that include coastal areas and / or small islands, regions borders with other countries, disaster-prone areas, entry areas persistence in the category of food, and tourism regions. Provision data on the specificity of the Minister of Finance to coordinate regional with related institutions.

Technical criteria are criteria that reflect the condition of facilities and infrastructure of each field. Areas of facilities and conditions poor infrastructure will be prioritized to get DAK. The criteria set by the relevant technical ministries. In DAK allocation calculations, the amount of technical criteria formulated as index technical fiscal (IFT). DAK allocated to each Regions based on the calculation of the General criteria, Specific criteria, Technical criteria and areas particular attention to the need of specific treatment.

Based on the regulation, there are a number of procedures to be performed in the DAK allocation to each region. These steps are systematically is as follows: first determine whether the area meets the general criteria, namely the area has fiscal capacity below the national average fiscal capacity: If it meets the general criteria indicated with Netto Fiscal Index (NFI), then the area is worthy of the DAK allocation and If it does not meet, then see the first specific criteria, namely whether the area is an area that is included in the specific autonomy arrangements and including disadvantaged areas. If included then automatically the area deserve DAK allocation.

If the area is not included in the specific criteria in point two, then refer back to the second specific criteria, namely territorial characteristics indicated by the Territorial Characteristics Index (IKW). After that, we should combine IKW to produce IFN and Regional Fiscal Index (IFW), if the area has IFW is greater than one, then the area is automatically deserving of DAK allocation.

As a conclusion, from the above bullet points, areas which deserve the DAK allocation is: areas that have a fiscal capacity below the national average, areas that include specific autonomy and disadvantaged areas and also IFW areas having greater than one.

From all areas worthy of DAK allocation, determined weight of a region (BD) by multiplying the value of the IFW Construction Cost Index (CCI). Worthy of all the regions are also determined index value Technical (IT) from each field, and then calculated weights Technical (BT) by multiplying IT with CCI. DAK allocation amount for each field specified by Weight of DAK is an amalgamation of BD and BT.

In 2006, DAK allocated only for nine sectors; education, health, roads, irrigation, drinking water, infrastructure, government, marine and fisheries, agriculture and the environment. Subsequently, in the year 2008 increased two areas, namely the field of family planning (FP) and forestry. For 2009 increased two areas also are trade and rural areas of infrastructure, so into thirteen fields. With the drinking water separation and DAK DAK sanitation in the previous year standing in a field, then DAK field in 2010 to fourteen fields. DAK field in in 2011 increased to nineteen fields. As for the additional 5 new fields that rural electric field, housing and settlements, land transport safety, transport rural infrastructure and border areas.

In the planning and allocation mechanism for DAK, consist of several activities such are setting of program and activities, DAK simulation, determination of the allocation and the use of Specific Allocation Fund and budgeting of Specific Allocation Fund. For the activity 1, we should stated DAK allocated in the state budget according to national priority programs contained in the budget RKP concerned. Line Ministry proposes specific activities that will be funded from the DAK and determined after coordination with the Minister of Home Affairs, Ministry of Finance, and Minister 
of State for National Development Planning, in accordance with the RKP.

For the 2nd step, DAK calculation is done through two phases; determination of the specific areas that receive DAK and also determination of the amount of DAK allocation of each area. Determination of Specific Areas must meet the general criteria, specific criteria and technical criteria. DAK allocation amount of each region is determined by calculating an index based on the general criteria, specific criteria and technical criteria.

For the rest activities, we can describes that DAK allocation per area defined by the Regulation of the Minister of Finance issued shortly after the State Budget Law. Based on the determination of DAK allocation, Line Ministry prepare Technical Guidelines for Use of DAK, no later than 2 weeks after the PMK set. Areas receiving it shall state the allocation and use of DAK in the budget. DAK can be done in accordance with the Technical Instructions DAK. DAK can not be used to fund the administration of the activities, preparation of physical activities, research, training, and business travel DAK allocation amount of each region is determined by calculating an index based on the general criteria, specific criteria and technical criteria.

\section{CONCLUSION}

Based on the analysis of the mechanism of transfer to the regions in Indonesia, to answer the first research question, it is possible to enlarge of DAK field for energy efficiency by asking Line Minister to proposed mechanism and send to the Ministry of Finance. To answer the second research question, developing DAK for energy efficiency can be addressed to support the achievement of environmentally friendly activities and reduce the burden of state budget subsidies. Some of things that must be done is to propose the allocation of DAK EE into government programs and to develop a variety of specificized and technical indicators related. To monitoring and evaluating DAK efficiency energy, at the initial step, we could rely on the existing regulation regarding the DAK mechanism on the intergovernmental transfer.

\section{REFERENCES}

Anonymous, 2012. Peer Review on Low Carbon Energy Policies in Thailand Final Report, the APEC Energy Working Group. Bangkok.
Blumstein, C. Kreig, B. Schipper, L and York, C., 1980. Overcoming Social and Institutional Barriers to Energy Efficiency. Energy, 5(4):355-371.

Golove, W.H., and Eto, J.H., 1996. Market Barriers to Energy Efficiency: A Critical Reappraisal of the Rationale for Public Policies to Promote Energy Efficiency. LBNL, Berkeley. Pp 66.

Grüning, C., Menzel, C., Panofen, T., and Shuford, L.S., 2012. Case Study: The Thai Energy Efficiency Revolving Fund. Frankfurt School of Finance \& Management gGmbH. Frankurt.

Hinge, A. Bertoldi, P., and Waide, P., 2004. Comparing Commercial Building Energy Use Around the World; The 2004 ACEEE Summer Study on Energy Efficiency in Buildings

Jaffe, A.B., and Stavins, R.N., 1994. EnergyEfficiency Investments and Public Policy. The Energy Journal, 15(2):43-65.

Kirsch, I., 1993. Adult Literacy in America: A First Look at the Results of the National Adult Literacy Survey. Website : http://literacy. kent.edu/Oasis/Pubs/nalsrev.htm.

Lovins, A., 1976. Energy Strategy: The Road Not Taken? Rocky Mountain Institute. Website : www.rmi.org.

Robinson, J.B., 1991. The Proof of the Pudding: Making Energy Efficiency Work. Energy Policy, September, pp 631-645.

Stern, P.C., 1986. Blind Spots in Policy Analysis: What Economics Doesn't Say about Energy Use. Journal of Policy Analysis and Management, 5(2):200-227.

Sanstad, A.H., and Howarth, R.B., 1994. Normal Markets, Market Imperfections, and Energy Efficiency. Energy Policy, 22(10):811-818.

Setyawan, D., 2013. Formulating Revolving Fund Scheme to Support Energy Efficiency Project in Indonesia, Energy Procedia Journal, 47:37-46.

Suminto, 2003. Beberapa Catatan Tiga Tahun Desentralisasi Fiskal. Majalah Anggaran, (edisi khusus), Jakarta.

Sutabur, T., 2012. Finance Energy Efficiency Projects through Financial Institutions: Energy Efficiency Revolving Fund. Department of Alternative Energy Development and Efficiency. Ministry of Energy. Thailand, Bangkok.

Sutherland, R.J., 1994. Energy Efficiency or The Efficient Use of Energy Resources?. Energy Sources, 16:257-268. 